\title{
第37回 日本細菌学会九州支部総会
}

\author{
会 長 永山在明（佐賀医科大学医学部微生物学教室） \\ 期 日 昭和59年11月17日（土），18日（日） \\ 会 場佐賀医科大学医学部臨床大講堂
}

\section{目次 \\ 特別講演}

生物のか犬さと柔らかさ一発生研究の教えるもの一… …岡田節人 (京大・理)

\section{一般講 演}

1. Candida albicane の germ tube 形成のための新し い培地……長 環, 林 幸男, 津野直子, 上西 秀則，萩原義郷（福曾大・口腔細菌）

2. Candida albicans から分離した菌系型発育を示さな いステロール変異株について……下川 修, 塩田 佳子, 中山宏明 (九大・雪・細菌)

3. カンジダ経気道感染に対する肺局所防御機構の解析 ……シャムラル, 光山正雄, 天児和暢（九大·医・ 細菌)

4. 人らい菌および鼠らい菌の $\mathrm{pH}$ 安定性……吉竹洋 子, 中村昌弘 (久留米大・医・細菌)

5. Mycobacterial plasmids: potential vectors and relationship to antibiotic resistance...... OFranzbrau, S.G., 中村昌弘 (久留米大・医・細菌)

6. セラチアの持つプラスミドと線毛について…… 本 剛, 水之江義充 ${ }^{1)}$, 守屋哲博 ${ }^{1)}$, 天児和暢 ${ }^{1)}$ (福 岡大・医・微生物, ${ }^{12}$ 九大・医・細菌)

7. 黄色ブドウ球菌の培養細胞への付着性……梅田昭 子, 植木祐司, 天児和暢 (九大・医・細菌)

8. ケニアに括ける小児の細菌性下痢症……渡辺繁 徳, 江原雅彦, 一瀬休生 (長崎大・熱研), 霜鳥翔一 (九大・医短大)

9. EPEC Survey in Kenya in $1983 \cdots \cdots$. 江原雅彦, 渡辺繁徳, 一瀬休生 (長崎大・熱研), 霜鳥翔一(九 大・医短大)
10. 伝達性の大腸菌のクエン酸利用能……伊津野保, 田上省三（熊本大・教育, 医短大)

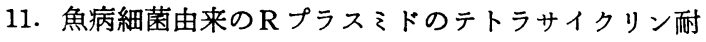
性遺伝子の起源について……高橋 厚, 青木 宙, 北尾忠利 (宮崎大・農・水産衛生)

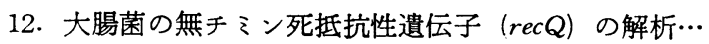
…中山浩次, 入野信人, 中山宏明 (九大 - 菌 - 細 菌)

13. マイコバクテリアの薬剤耐性遺伝子の大腸菌へのク ローニングの試み……水口康雄, 谷口初美, 有働 武三（産業医大・微生物）

14. Mycoplasma faucium 分離株の增殖に及ぼすビ夕る ンの影響……武田朋子, 中村昌弘（久留米大·医・ 細菌)

15. マイコプラズマ発育阻止物質の本態並びに作用機序 ……伊藤 亨, 中村昌弘 (久留米大・医・細菌)

16. MV-01 ウィルスの核酸の性状……市丸弘子, 中 村昌弘（久留米大・医・細菌）

17. イヌを用いた大腸全摘術後の腸内細菌叢の変動…… ○小畠敏生，中村昌弘 (久留米大・医・細菌)

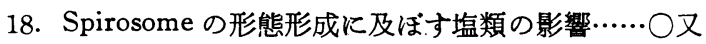
吉盛健，小田 紘（鹿児島大・医・細菌）

19. Bacteroides による Eubacterium の $7 \alpha$-脱水酸化 促進作用……高嶺房枝, 今村禎祐（琉球大 - 医 保健)

20. 海水より分離された Cytophaga によるカラギーナ ン分解酵素の 産生について…… OGolam Sarwar, 小田 紘（鹿児島大・医・細菌）

21. 慢性関節リウマチの病因としての細菌感染因子の意 義……过 幸作，中村昌弘 (久留米大·医・細菌)

22. Mycoplasma salivarium 細胞膜からの aminopeptidase の可溶化の試み……柴田健一郎, 戸塚昌攻, 渡辺継男（長崎大・畗・口腔細菌）

23. 川崎病患者由来プロピオン酸菌の毒素産生……吕山 
本 繁, 近藤正治, 浦川豊彦, 新宮正久(久留米大·

医・ウイルス)

24. アポセルロプラスミンをリガンドとしたアフィニテ イクロマトグラフィーによる百日せき毒素の精製…

․作間 晋, 坂本国昭, 江藤 晶, 北川 久, 酒 匂光郎 (化血研)

25. タンク培養由来による百日せきコンポーネントワク チン製造の検討……銀永明弘，西原 司，平嶋貞 弘, 木庭博司, 江口 文, 作間 晋, 相原勝敏, 北 川 久, 酒匂光郎, 鈴木洋二1), 今泉 厚 ${ }^{1)}$, 佐藤勇 治2)(化血研，1)帝人生医研，2)予研)

26. 高 $\mathrm{pH}$ 培養条件下で出現するコレラ菌の線䋐状構造 物……霜鳥翔一, 天児和暢, 高出明美（九大·医・ 細菌)

27. 1983年ケニア国分離コレラ菌の性状……正瀬休 生, 江原雅彦, 渡辺繁徳 (長崎大 - 熱研), 霜鳥翔一 （九大・医短大）

28. エルトール，NAG ビブリオ西溶血素の同一性…… ○山本耕一郎, 仲宗根昇, 田辺将夫, 岩永正明 (琉 球大・医・細菌)

29. コレラ菌の毒素産生に影響を扣よぼす諸因子につい $\tau$ ‘.....岩永正明 ${ }^{1)}$, 田辺将夫 ${ }^{1)}$, 山本耕一郎 ${ }^{1)}$, 仲 宗根昇 ${ }^{1)}$, 江原雅彦 ${ }^{2}$, 内藤達郎 ${ }^{2}{ }^{(1)}$ 琉球大・医・細 菌， ${ }^{2}$ 長崎大・熱研・細菌）

30. コレラ毒素の LPS との結合による無毒化と免疫原 性について……徳永英治, 今川義孝, 村岡東洋治, 大友信也，近藤誠一*，久恒和仁 ${ }^{*}$ (化血研, *城西 大・薬)

31. マウス・サイトメガロウイルスに対するモノクロー ナル抗体……岡田政信, 栄鶴義人, 南嶋洋一 (宮 崎医大・微生物)

32. 七上血清中 ATL 関連抗体の解析……森内良三, 片峰 茂, 日野茂男, 宮本 勉, 木下研一郎（長崎 大・医・細菌)

33. 腫痬細胞溶解力をもつウシェンテロウイルスの型別 ……松浦秀二, 新宮正久 (久留米大・医・ウイル ㅈ)

34. 担癌ヌードマウスに拈ける偶蹄類エンテロウイルス の効果……新宮正久, 浦川豊彦, 今村宜寬 (久留 米大・医・ウイルス)

\section{要旨}

\section{一般講 演}

1. Candida albicans の germ tube 形成のための 新しい培地

○長 環, 林 幸男, 津野直子, 上西秀則, 藏原義 郷（福歯大・口腔細菌）

二相性真菌 Candida albicans の菌糸形発現のメカニズ ムを解明するために菌系形成の第一段階である germ tube 形成を指標とし, その形成用液体培地の作成を試 みた。

グルコース・ペプトン・酵母エキス培地 (GPY) で 37 C 25時間静置培養後の Candida albicans ATCC 1002 株を用いて調整した約 $2 \times 10^{6} \mathrm{CFU} / \mathrm{m} l$ の菌液を, リノ 一ル酸・チオプロリン・L-プロリン・重炭酸ソーダを 含む培地 (LTPC) に加兄， $37 \mathrm{C} 3$ 時間振とうを行つた ところ，約 $90 \%$ germ tube 形成を示した。

今回はこの LTPC 培地を得るに至つた種々の検討事 項怙よびこの培地を用いて germ tube 形成に及ぼすチ オプロリンの影響について検討したので報告する。

\section{Candida albicans から分離した菌系型発育を示} さないステロール变異株について

○下川 修，塩田佳子，中山宏明（九大・歯・細菌）

真菌細胞膜に抢けるステロールの存在意義は未だ不明 だが，その機能の一側面を示唆する変異株を得たので報 告する。この変異株 $\mathrm{KD} 4700$ はリシン要求変異株 $\mathrm{KD}$ 14 (Candida albicans, serotype A) から紫外線照射に よりアンホテリシンBに対する抵抗株として分離した。 KD 4700 はナイスタチン， ピマリシン拈よびフィリピ ンのポリエン抗生物質に対して交差耐性を示し，脂質画 分の全ステロール量には親株との差はないものの, スペ クトル分析ではエルゴステロールの顕著な減少が見られ た。かつ KD 4700 はコーンミール寒天培地上で菌糸形 成を示さなかつた。また KD 4700 は長期平板培養で菌 苔上にパピラを形成したが，パピラから分離した株はポ リエン感受性，スペクトルおよび菌糸形成能のすべてが 親株 KD 14 と殆んど一致する復㷌株であつた。上記の 結果はステロールの変化と菌系形成の関連性を示唆す る。薄層クロマトグラフィーによるステロールの分析に より，KD 4700 はエルゴステロールが減少し，ほかの 
中間体ステロールが蓄積していることを示す結果が得ら れた。

\section{3. カンジタ経気道感染に対する肺局所防御機構の解} 析

○シャムラル, 光山正雄, 天児和暢 (九大 ・医・細菌) 肺胞マクロファージ $(\mathrm{AM} \phi)$ の存在する肺におけるカ ンジダ (C. albicans) 飞対する局所防御の特性を解析し た。マウスはカンジダ経気道感染に対し，腹腔感染より も強い抵抗性を示す。この抵抗性は，線全身照射で障害 されるがカラギーナン (CA) 処理では変化がないこと が, 感染死亡率, 肺内菌数の変動から明らかとなつた。 気道洗浄法により肺内細胞の変動をみると, 感染後, 多 核白血球 $(\mathrm{PMN})$ の浸出が高度にみられ，X線照射マウ スでは $\mathrm{AM} \phi$ は不変であるのに $\mathrm{PMN}$ 反応が強く抑制

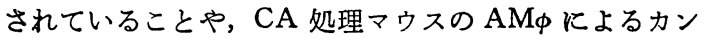
シダ貪食能は低いにもかかわらず抵抗性が保たれている ことから， $\mathrm{AM} \phi$ の存在よりも $\mathrm{PMN}$ 反応が肺局所防御 に役立つているらしい。一方, 経気道致死的感染に対し て, 生菌, 死菌の経気道免疫のみが強い防御を誘導し, 腹腔免疫は無効であつた。経気道免疫マウスでは，攻撃 感染後著明な $\mathrm{PMN}$ 反応の昂進と感染菌の排除がみとめ られた。免疫により PMN の集合を促進する機序が成立 するものと考えられた。

\section{4. 人らい菌および鼠らい菌の pH 安定性}

○吉竹洋子，中村昌弘 (久留米大・医・細菌)

演者らは, 鼠らい菌および人らい菌の人工培地での培 養の研究を長年続けている。

今回は，生物活性を検出する一つの手段として，ATP 活性を測定し，異なる $\mathrm{pH}$ 下に㧍ける各菌の状態を比較 検討し，いかなる条件でもつともよく，それらの菌の活 性が維持されるかを調べ，培地作製の参考にしようとし た。

供試溶液は， $\mathrm{M} / 15$ のリン酸楥衝液を用い， $\mathrm{pH}$ を 6.0 から 7.2 まで 4 段階あるいは，5段階に調製した。さら に，最終濃度が，10\%になるように，Calf serumを添加 した。

ATP 活性の測定には, luciferin-luciferase 系を用い, 上記の系に各菌を接種し，30Cで培養したものについ て, ある一定の間隔（2〜3 週）毎に ATP の測定を行 つた。

その結果，両菌とも，予想以上の長期にわたつて，生 物活性を示した。また，この条件下に拈ける人らい菌の
至適 $\mathrm{pH}$ は，7.2，鼠らい菌のそれは， $\mathrm{pH} 6.6$ であろ らことが示唆された。

5. Mycobacterial plasmids : potential vectors and relationship to antibiotic resistance

OFranzbrau, S.G., 中村昌弘 (久留米大 - 医・細菌)

Screening for mycobacterial plasmids was undertaken to 1) obtain potential vectors for gene transfer among mycobacteria and 2) to determine plasmidcoded functions, including drug resistance. A modification of a published technique was employed for plasmid detection. To date we have screened 47 mycobacterial strains, including 33 clinical isolates of Mycobacterium avium-intracellulare (MAI) and 5 . of Dr. V. R. Khera's "in vitro adapted M. leprae" isolates. The 1-3 plasmids were detected in approximately $50 \%$ of the clinical MAI. Plasmid DNA was not detected in any of the other isolates screened. All plasmid + MAI showed high level resistance to kanamycin, streptomycin and rifampinand most formed translucent colonies. Conversly, plasmidMAI demonstrated a range of antibiotic sensitivities. with most being relatively susceptible to rifampin and forming opaque colonies.

\section{6. セラチアの持つブラスミドと線毛について}

○山本 剛，水之江義充 ${ }^{1)}$ ，守屋哲博 ${ }^{12}$ ，天児和暢 ${ }^{1)}$ (福岡大・医・微生物，1)九大・医・細菌)

臨床分離されたセラチア株のプラスミドと，薬剤感受 性，線毛の遺伝支配との関連を検索した。プラスミドの 抽出には簡便法を用い，90株の検索を行つた結果，尿路 感染株は65\%がプラスミドを保有していたが，呼吸器感 染株には保有株がみられなかつた。薬剤感受性試験には トリディスク法を用い，10種類の抗生剤に対する感受性 を調べた。 $\beta$-ラクタム系抗生剤に対する感受性は従来の 報告ど括り低かつたが，これまで有効とされていた，ク ロラムフェニコール，ゲンタマイシン，テトラサイクリ ン，ナリシクス酸に対し，尿路感染株で耐性菌の増加が 顕著であつた。プラスミドと線毛との関係は，エチジウ ムブロマイドによるプラスるドの除去ならびに形質転換 によつて調査した。プラスミド保有株で線毛を持つ10株 について実験を行つた結果, US 28 株の持つマンノース 耐性線毛と US 50 株の持つマンノース感受性線毛がプ ラスミドの除去によつて消失し，ニワトリ赤血球凝集能 
も失なわれていた。同時に薬剤感受性も变化しているこ とから，同じプラスミド上に線毛と薬剤耐性の遺伝子が 存在するものと思われる。

\section{7. 黄色ブドウ球菌の培養細胞への付着性}

○梅田昭子, 植木祐司, 天児和暢（九大・医・細菌） 黄色ブドゥ球菌の培養細胞への付着因子について, Vero 細胞を用いて検討を行つた。菌の細胞への付着に は，蹯水性結合反応が考えられるため，キシレンを用い て菌の疎水性を調べた結果, 細胞に高率に付着する菌は いずれも高い疎水性を示した。そこで，菌に種々の処理 を行い，その付着性と柾水性の関係を調べた。菌を種々 のタンパク分解酵素で処理すると，いずれも細胞への付 着性はほとんぞ無くなり，親水性に変化した。 $45 \%$ フ ノール熱処理を行つたるのは，高度の踈水性を示し細胞 への付着性に変化は見られなかつた。10\% TCA 処理を 行つたものは，親水性に変化したが，細胞への付着性は 菌株による差が見られた。

以上の結果から，ブドウ球菌の細胞への付着には細胞 壁に存在する䠅水性タンパクが密接に関与していること が考兄られる。また，菌の表面に存在するタンパクを 125I でラベルし SDS 電気泳動により検討すると, 細胞 壁タンパクの大部分は菌の表面に露出していると思われ る結果が得られた。

\section{8. ケニアにおける小児の細菌性下痢症}

○渡辺繁徳, 江原雅彦, 一瀬休生 (長崎大 - 熱研)，霜 鳥翔一（九大・医短大）

ケニア国モンバサ市において，Campylobacter jejuni (CJ)，および毒素原性大腸菌 (ETEC) を対象とした小 児下痢患者の感染状況を調查した。モンバサ市にある 2 つの医療施設に下峲を主訴として受診した 0 嵗から14歳 までの小児患者より 782 名の検便を行つた結果， 277 例 $(35.0 \%)$ より病原菌を分離した。そのうち，検出頻度の もつとる高かつたものは病原性大腸菌 (EPEC) 127 例 (17.3\%) であり，以下 CJ 98例 (12.5\%), ETEC 47例 (6.0\%)，そのほか42例 $(5.4 \%)$ の順であつた。CJ 検 出例のうち，77例は単独感染であったが，残り21例は EPEC, ETEC や赤痢菌などとの重複感染例で, そのう ちの 3 例は三重感染であつた。また，ETECにおいても 10例が重複感染であつた。ETEC の毒素型は ST 産生 型がもつとも多く, 次いで LT 産生型, 両毒素産生型は わずか 2 例にすぎなかつた。

\section{日本細菌学雑誌 $40(3), 1985$}

\section{EPEC Survey in Kenya in 1983}

○江原雅彦，渡辺繁徳，一瀨休生 (長崎大・熱研)，霜 鳥翔一（九大・医短大)

病原性大腸菌 (EPEC) の保菌者の動態を把握するた め，Kwale 地区の住民約 400 人から 約 3 力月間隔 で 3 回，検体 (Rectal swab) を収集し，菌検索を行つた。 各検体からE. coli 3 colony ずつ拾つて市販の EPEC 抗血清（デンカ生研）による凝集で，型別を行つた。毎

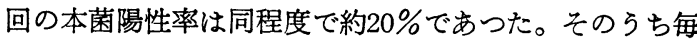
回陽性であつたのは 1 例のみで， 2 回陽性は19例あつた が，いずれも異なつた血清型を示していた。すなわち， 同一血清型株の再感染は認められず，病原性大腸菌の場 合にる long term immunityを考虑する必要があるこ とを示唆するものとみられた。 sample 提供者はすべて 健康であつた。また，Cholera Survey, C. jejuni Survey などで集めた E. coli もすべて凝集を行い，約 2,000 人 からのデータをまとめて EPEC の保菌率，型別，ETEC 検出率，性差，年齢差，地域差，健康者々下浰患者間の 検出率の相異などに検討を加えたので報告する。

\section{0. 伝逵性の大眗菌のクエン酸利用能}

○伊津野保，田上省三（熊本大・教育，医短大)

Simmons のクエン酸培地に発育しないことが大腸菌 分類の重要な指標とされているが，われわれは一昨年の 本学会に打いて，大腸菌を同培地上で長期間培養すると その多くが発育を示すことを報告した。その後培養18カ 月以上で始めて発育を示した菌を同培地上で10代継代し て比較的短時日に安定して発育を示するの25株を分離し た。それについてストレプトマイシンを含む 8 種の抗生 物質に対する感受性をしらべ，さらにそのクエン酸利用 能が汪かのクエン酸陰性の大腸菌に容易に伝達されるこ とを知つたのでその成績について報告する。

11. 魯病細菌由来のRブラスミドのテトラサイクリン 耐性速伝子の起源について

○高橋 厚, 青木 宙, 北尾忠利 (宮崎大 - 農 - 水産 衛生)

われわれは，すでに種々の魚類病原菌の薬㓮耐性株よ りRプラスミドを検出し，その性状扰よび遺伝子構造を 明らかにした。 Rプラスミドがコードするテトラサイク リン (TC) 耐性遺伝子はすでにその DNA 構造より 4 種類 (A型: RP 4, B 型: R222 ( $\mathrm{Tn}$ 10), C型: pBR 322, D型：RA 1）に大別されている。しかし魚類病原 菌由来の $\mathrm{R}$ プラスミドの $\mathrm{TC}$ 耐性遺伝子については詳細 
な研究はなされていない。そこでわれわれは魚類病原菌 Aeromonas hydrophila, A. salmonicida, Edwardsiella tarda, および Pasteurella piscicida 由来のRプラス ドについて DNA を調整し，TC 而性遗伝子をクロー ン化し，Southern blotting 法にて，相同性を求め，TC 耐性遺伝子の分類を行つた。A. hydrophila, E. tarda

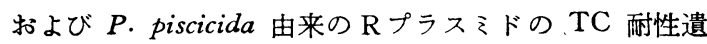
伝子はD型に, A. salmonicida の一部は, C型に属した。

\section{2. 大渴菌の無チミン死抵抗性遗伝子 $(\operatorname{rec} Q)$ の解析}

○中山浩次, 入野信人, 中山宏明 (九大・歯・細菌) 大腸菌の無チミン死抵抗性 (TLD ${ }^{\mathrm{r}}$ ) 変異株 HN 15 の 解析より, TLD 変異は遺伝子地図上の ilv-met $E$ 間に 存在すること扣よびこの領域を $r e c B C s b c B$ 遺伝的背 景に移すと紫外線感受性の上昇 (UVs)，接合組及換え能 の低下 $\left(\mathrm{Rec}^{-}\right)$をすたらすことがわかつており，これら の性質は同一の変異により生じることが示唆されていた が，今回はこの遺伝子 (rec Q) のクローニングにより， 上記を確認する結果を得た。すなわら，1） $\operatorname{cor} A$ 遺伝子 領域をもつ低コピー数型プラスミド $\mathrm{pKD} 3$ は, TLD ${ }^{\mathrm{r}}$ を抑制するとともに, rec $B C s b c B$ 遺伝的背景に拉ける UVs, Rec-をも抑制すること。2) プラスミド上のこの 遺伝子に対する $\operatorname{Tn} 3$ 挿入変異 ( rec $Q: ： \operatorname{Tn} 3)$ とそ のクロモゾームへの移行により，挿入変異は上記の性質 をすべてもつこと，3）マキシセル法によりこの遺伝子 産物の分子量は $78 \mathrm{~K}$ であること, がわかつた。

この領域にはこのような性質をむつ遺伝子は知られて いないことから, rec $Q$ 遺伝子は遺伝的組又換えの Rec F 経路に係わる新しい遺伝子であると思われる。

\section{3. マイコバクテリアの薬剤耐性遗伝子の大閶菌への}

\section{クローニングの試み}

○水口康雄, 谷口初美, 有働武三 (産業医大・微生物) マイコバクテリアの遺伝子の大腸菌での情報発現を調 ベるためのモデル系として $M$. fortuitum の有するアミ ノグリコシドアセチル化酵素および $\beta$-ラクタマーゼ産生 遺伝子に注目し，これら遺伝子のクローニングと大腸菌 での情報発現の有無について検討した。 $M$. fortuitum $\mathrm{EH}$ 株より抽出した DNA は, BamHI, SaII, PstI など, その認識部位が GC に富む制限酵素では良く消化され多 数の断片が生じたが, Hind III, Eco RI, Eco RV のよ らな AT に富む配列を認識する制限酵素には抵抗性を 示した。これらの酵素で処理した DNA を pBR 322 ま たは pACVC 184 に結合, C600 株に導入して gene bank を作成した。これらの transformant がマイコバ クテリアの DNA を有していることを確認後, アミノグ リコシドおよび $\beta$ •ラクタム抗生剤に対する耐性発現の有 無を検討したが，十分な数の transformant について調 ベたにもかかわらず耐性を発現したクローンはまつたく 得られなかつた。これら遺伝子の大腸菌に拈ける情報発 現が行われない理由はいくつか考えられるが，放線菌の 場合と同様, プロモーター部の違いによる可能性が高い ものと思われる。

\section{Mycoplasma faucium 分離株の增殖に及ぼすビ タミンの影邹}

○武田朋子，中村昌弘 (久留米大・医・細菌)

口腔より分離された Mycoplasma faucium T39 株の 分離増殖用培地 (PPLO 液体培地) に拈ける増殖が, 数 回にわたる継代にもかかわらず，低調であり，同じ口腔 より分離される $M$. salivarium の分離率に比べて $M$. faucium の分離率が非常に低率であることなどから， $M$. faucium の増殖を向上させることと, 分離率を高めるた めに, まず, ビタミンの $M$. faucium の増殖に及ぼす影 響を検討した。

ビタミンは， $\mathrm{B}_{1}, \mathrm{~B}_{2}$ をはじめとする18種を用いたが， いずれも増殖促進はなくビタミン $\mathrm{B}_{1}, \mathrm{H}_{1}, \mathrm{~K}_{3}, \mathrm{~K}_{5}, \mathrm{M}, \mathrm{P}$ などは，かえつて増殖抑制を示した。中でも，ビタミン $\mathrm{B}_{2}$ では, 著明な増殖抑制が認められた。そこで, ビタミ ン $\mathrm{B}_{2}$ の濃度について検討し, 対照とした M. salivarium $(\mathrm{NIH}), M$. pneumoniae Mac 株との増殖態度に違いを 見い出したので，ほかの検討結果も加えて報告する。

\section{5. マイコブラズマ発育阻止物埛の本態並びに作用機} F5

○伊藤 亨, 中村昌弘 (久留米大・医・細菌)

われわれはさきに細胞破壊により得られるマイコプラ ズマ発育阻止物質 usMcin の発育阻止活性パターンが M. fermentans の場合を除き, Arginine 分解活性とよ く相関することを見出した。

その後の研究で各種マイコプラズマにつき再度, usMcin 活性パターンを調ベたところ, Arginine 分解種 は, usMcin 産生能も，それに対する感受性もともに陽 性で, Arginine 非分解種は, その逆の成績を示すこと が判明した。

そこで，今回は usMcinの本態並びに作用機序を解明 すべく，高速液体クロマトグラフを用いて，usMcin の 精製を試み，そのアミノ酸分析およびマイコプラズマ膜 
たんぱくのアミノ酸分析を行つたのでその成績を報告す る。また, usMcin の末端アミノ酸および usMcin 感受 性マイコプラズマの receptor の証明に関する研究す続 行中である。

\section{MV-01 ウイルスの核酸の性状}

○市丸弘子, 中村昌弘 (久留米大・医・細菌)

既に報告した新しいウイルス，MV-01 は，Acholeplasma oculi $19 \mathrm{~L}$ の cloning 中に自然に分離されたウイ ルスであるが，その自然誘発に至つた過程を明らかにす る目的で，MV-01 の核酸の性状の検討した結果を報告 する。MV-01 の核酸抽出物は, DNase Iによつて消化 され, diphenylamine 法によつて DNA が検出された ことより，MV-01 は DNA ウイルスであることが確認 された。MV-01 の DNA は, Tm=82C, G+C=31(\%) と低い $\mathrm{G}+\mathrm{C}$ 含量を示した。また, ethidium bromide による dye titration, nuclease SI による酸可溶性分画 の生成などの結果より，MV-01 DNA は環状二重鎖 DNA であることが示唆された。制限酵素 Pst 1，ある いは Ban III により生じた DNA 断片の分子量の合計 より MV-01 DNA の分子量を推定したところ $1.1 \times 10^{7}$ daltons (16 kbp) であつた。MV-01 DNA と宿主遺伝 子との関連性については，まず Lysogeny の可能性を考 え，目下検討している。

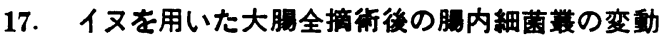

○小畠敏生, 中村昌弘 (久留米大・医・細菌)

大腸全摘術後に起こる異常な腸液増加の原因と機序を 解明するためイヌを用いて大腸全摘回腸直腸吻合術を行 い, 術後の腸内細菌叢の変化を検討した。その結果, 次 の成績を得た。

1）術直後は, 水様便であつたが次第に泥状から軟便 へと変わる傾向があるすのの異常腸液增加には至らず, ヒトの異常腸液増加をイヌを用いた動物実験で再現する ことはできなかつた。

2)この際の腸内細菌叢の変動は, 好気性菌ではその 検出菌の種類, 菌数が術前とほぼ同じであり相対的な增 加として認められた。また嫌気性菌では術後，1 年して \& Bacteroidaceae, Eubacterium, Peptococcaceae, レシ チナーゼ陰性 Clostridium がいずれす減少していたが, その程度は約 $10 \%$ で著明な増減を示さなかつた。

これらの結果より, 腸内細菌叢が適切な均衡を保つか ぎり異常な腸液排泄は起こらないであろうことが示唆さ れた。

\section{Spirosome の形態形成に及ぼす塩類の影翌}

○又吉盛健，小田 紘（鹿児島大・医・細菌）

先にわれわれは, Peptostreptococcus productus, Eubacterium lentum, Eubacterium aerofaciens, Lactobacillus fermentum および未同定の嫌気性グラム陽性無芽胞桿菌 HD-17 株などを PBS 中に婑濁し，弱く超音波処理する ことで，㹂濁液中に多数の spirosome が見出せることを 報告した。今回，これらの菌を蒸留水中で超音波処理す ると spirosome が見られず，その液に少量の $\mathrm{NaCl}$ を 添加するとただちに spirosome が見られるようになる ことを観察した。添加される $\mathrm{NaCl}$ の濃度と観察される spirosome の量は, $\mathrm{NaCl}$ 濃度 $50 \mathrm{mM}$ 以下では明らか な正の相関が見られた。また spirosome の瑟濁液 $10 \mathrm{ml}$ を $3,000 \mathrm{ml}$ の蒸留水で透析し, 㹂濁液中の $\mathrm{NaCl}$ をと り除くと $4 \sim 6$ 時間の間に spirosome が崩壊した。現 在, ほかの塩類の添加でも同様の効果があるか検討中で ある。

\section{Bacteroides による Eubacterium の $7 \alpha$-脱水酸 化促進作用}

今村禎祐, ○高嶺房枝 (琉球大・医・保健)

Eubacterium species $\mathrm{C}-25$ 株の $7 \alpha$-脱水酸化作用 が Bacteroides distasonis $\mathrm{K}-5$ 株の培養上清や菌体破壊液に より増強されることが鹿児島大学の平野らにより報告さ れている。今回 B. distasonis $\mathrm{K}-5$ 株の $7 \alpha$-脱水酸化促 進作用に関して，その菌体破壊液と Sephadex G-100 ゲ ルロ過画分を用いて，若干の性状について検討した。 $7 \alpha$-脱水酸化促進作用活性は Sephadex G-100 ゲルロ過 により第 1 ピークに溶出される。K-5 菌体破壊液や Se-

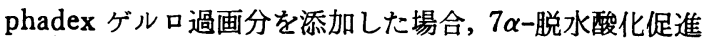
作用はたんぱく濃度に比例して認められる。 $7 \alpha$-脱水酸 化促進作用は空気中での冷凍および冷蔵保存において著 しく低下するが，真空下同条件においては 7 日後も残存 する。さらに， $60 \mathrm{C} ， 20$ 分の加熱処理により $7 \alpha$-脱水酸 化促進作用活性はほとんど失なわれる。

また, Eubacterium sp. C-25 は単独で弱い $7 \beta$-脱水 酸化作用を示し，B. distasonis K-5 株は $7 \beta$-脱水酸化も また著しく促進することを併せて報告する。

20. 海水より分離された Cytophaga によるカラギー ナン分解酵素の産生について

OGolam Sarwar, 小田 紘 (鹿児島大・医・細菌)

演者らは鹿児島県の錦江湾海中より，カラギーナン分 解酵素 (carrageenase) 産生能をるつ Cytophaga 12株 
を分離し報告した。これらの株の分離, 酵索活 性 の検 出，打よび継代は人工海水を基礎にした peptone yeast extract 培地 (ZoBell $2216 \mathrm{E}$ broth) とカラギーナンを 添加したすのを用いて行われた。今回は, 増殖および carrageenase 産生に対する無機塩類の影響について 調 べ次の結果を得た。1) carrageenase 産生には培地中に カラギーナンの存在を必要とした。2）人工海水中の無 機塩類のらち carrageenase 産生には $\mathrm{NaCl}$ と $\mathrm{MgCl}_{2}$ のみを必要とし, $\mathrm{KCl}$ と $\mathrm{CaCl}_{2}$ は必要でなかつた。3) carrageenase 産生に適した $\mathrm{NaCl} と \mathrm{MgCl}_{2}$ の最少量 は $0.05 \mathrm{M} \mathrm{NaCl}$ と $0.25 \mathrm{M} \mathrm{MgCl}_{2}$, または $0.15 \mathrm{M}$ $\mathrm{NaCl}$ と $0.15 \mathrm{M} \mathrm{MgCl}_{2}$ であつた。4) carrageenase は 增殖を抑制された条件下でる細胞内で産生されることが 認められた。

\section{1. 侵性関節リウマチの病因としての細蔨感染因子の 意新}

○过 幸作, 中村昌弘 (久留米大・医・細菌)

慢性関節リウマチ（以下 RA と略する）の病因を微生 物に求め続けているらち今日をで比較的見過されてきた ヒト常在微生物が関与しているのではなかららかといら 旋問をいたくく以下の成績を得た。

1） M. arthritidis の大量静眽内投与によりマウスの 関節よりかなり長期間にわたり $M$. arthritidis が分離 された。

2） SP-4 培地を用いて RA 患者関節液からのマイコ プラズマの分離を試みたところ，初代培養の SP-4 broth に color chage が認められ, マイコプラズマの存在が疑 われた。

3） RA 患者血清中の異種血球凝集素を乳酸菌により 吸収したところ，吸収は起こらず異種血球凝集反応の促 進が認められた。

\section{Mycoplasma salivarium 紬胞膜 からの amino-} peptidase $の$ 可溶化の試み

○柴田健一郎，户塚昌攻，渡辺継男（長崎大・㭔・口 腔細菌)

昨年の本学会に怙いて，M. salivarium の a minopeptidase (AP) 活性が細胞膜に局在していることを報告し た。今回，この AP の細胞膜からの可溶化を検討したの で，その成績を報告する。

超音波で破啸したのちに，DNase 抢よび RNase で 処理した M. salivarium 菌体の $40,000 \times \mathrm{g}$ 沈渣を, 夕 ンパク量が約 $2.0 \mathrm{mg} / \mathrm{m} l$ になるように, $0.15 \mathrm{M} \mathrm{NaCl}$
を含む $\mathrm{pH} 8.0$ の $0.1 \mathrm{M}$ borate buffer $飞$ suspend し, 出発材料とした。可溶化剂としては, SDS, DOC, Triton X-100, Brij 35, Tween 80, CHAPSO, Digitonin, Trypsin および Papain を用いた。その結果, AP $は$ Triton X-100, Brij 35, Tween 80, CHAPSO, Trypsin および Papain ではほとんど可溶化されず, $1 \%$ DOC で約 30\%, そして $0.2 \%$ SDS で約 50\% 可溶 化された。そこで, SDS の濃度を変えて, 可溶化の程 度を調べたところ，0.4\% 以上の濃度で約 $80 \%$ が可溶化 された。さらに，0.8\% SDS の共存下で，37C で6日 間 incubate しても，AP の失活はほとんどみられなか つた。

\section{3. 川崎病患者由来ブロピオン酸菌の㤠素産生}

○山本 繁, 近藤正治, 浦川豊彦, 新宮正久 (久留米 大・医・ウイルス

川崎病患者より分離した Propionibacterium acnes は 毒素活性（ヒト胎児肝由来細胞での封入体形成能）をす つ物質を産生し，継代によつてその活性が著しく減少し たが, Centriflo 沪過後 GAM ブイヨンに再浮遊するこ とにより活性の增強を来たしたことは既に報告した。こ の有効成分は GAM 構成成分中の消化血清末であること がわからた。そしてこれは毒素の熱に対する安定性を 增進した。この毒素浮遊液に対する患者血清の反応を見 たところ，後期血清では明らかに毒素活性の減少をるた らした。一方, 培養沪液の SDS-PAGE によつて2つあ るいは 3 つのバンドが見られ，これらは消化血清末に浮 遊した液にる確認でさた。このたんぱくが毒素活性と関 連があるかどらかは現在のところ不明であるがこの点に ついて検討中である。

24. アボセルロブラスミンをリガンドとしたアフィニ ティクロマトクラフィーによる百日せき萧素の精製

○作間 晋, 坂本国昭, 江藤 晶, 北川 久, 酒匂光 郎 (化血研)

百日せき毒素 (Pertussis Toxin 以下 PT と略す。) は，多彩な生物活性を有するたんぱく毒素として知られ ているが，百日せきに対する重要な感染防御抗原でもあ る。百日せきワクチンを製造するにあたり，このPTを 大量得ることが必要である。

従来，ヒトのハプトグロビンをリガンドとするアフィ ニティクロマトグラフィーにより，PT は高度に精製で きると報告されているが，混入する可能性のある生物体 や各種の感染因子を不活化する目的で, 公知の $60 \mathrm{C}, 10$ 
時間の加熱処理をおこならとハプトグロビンは，PTに 対する親和性をまつたく毠失する。

一方，ヒトのアポセルロプラスミンは，PTを特異的 に結合させ，上記の加熱処理によつても，PT との親和 性は低下しないことを見出した。このアポセルロプラス ミンを用いて，1段階で高純度のPTを大量に採取する ことが可能となり，しかも，発熱物質の除去にも有効で あつた。

以上のことから，アポセルロプラスミンをリガンドと するアフィニティクロマトグラフィーは，百日せきワク チンの一成分である PT の精製に適していることがわか つた。

25. タンク培兴由来による百日せきコンボーネントワ クチン製造の検討

○銀永明弘，西原 司，平沜貞弘，木庭博司，江口

文, 作間 晋, 相原勝敏, 北川 久, 酒匂光郎, 鈴木 洋二 ${ }^{1)}$ ，今泉 厚 ${ }^{1}$ ，佐藤勇治 ${ }^{2}$ (化血研， ${ }^{1}$ 帝人生医 研, 2)予研)

$\mathrm{MeCD}$ 添加培地 (第36回本学会) で百日咳菌をタンク 培養し, 該上清液からわれわれ独自の方法で高純度の PT と F-HA を扰の扰の精製，減毒化し，Component ワクチンを試作した。培養上清液 $280 \mathrm{~L}(2,500 \mathrm{~F} \cdot \mathrm{HA}$ 一 E. u., 1, 700 PT-E.u., 1, $024 \mathrm{HA}, 60 \mu \mathrm{g} \mathrm{PN} / \mathrm{m} l)$ を Apoceruloplasmin ゲルクロマトで PT を高度に，かつ Pyrogen-free 飞精製し $(17,000$ PT-E. u., < $<5$ F.HAE.u., $64 \mathrm{HA}, 30 \mu \mathrm{g} \mathrm{PN} / \mathrm{ml}, 22 \mathrm{~L}$ ), そのゲルの素通り 画分を Sulfonated Polysaccharide ゲルクロマトでF . HA を高度に精製した $(50,000$ F-HA 一E. u., 20, 480 $\mathrm{HA}<5 \mathrm{PT}-\mathrm{E}$. u., $70 \mu \mathrm{g} \mathrm{PN} / \mathrm{m} l, 13 \mathrm{~L})$ 。この两者のト キソイドの最終濃度が，ともに $8 \mu \mathrm{g} \mathrm{PN} / \mathrm{ml}$ ， あるいは $4 \mu \mathrm{g} \mathrm{PN} / \mathrm{m} l$ などになるように任意に混合した各沈降精 製百日陔 Component ワクチン报よびこれを用いた各沈 降 DPT ワクチンは，とすにすぐれた力価と安全性を示 した。

\section{6. 高 pH 培粉条件下で出現するコレラ菌の線樴状粠 造物}

○霜鳥翔一，天児和暢，高出明美（九大・医・細菌） コレラ菌を $0.1 \%$ 以上の濃度に $\mathrm{NaHCO}_{3}(\mathrm{pH} 7.5)$ を 加えた Tryptic Soy Broth (Difco) で培養 (37C 18 hrs) すると，菌体周囲に 不規則に配列した 線繊状構造 物が，シャドウイングした試料の電顕観察により容易に 見出される。この構造物の発現には，培地中に $\mathrm{NaHCO}_{3}$
つ存在が必須条件であって, $\mathrm{NaHCO}_{3}$ の代りに $\mathrm{NaOH}$ を用いて $\mathrm{pH}$ を調整しても認められない。

また，通常のペプトン水に $\mathrm{NaHCO}_{3}$ を加えただけで は見出されないが，1\%に Yeast extract を添加するこ とにより出現する。

$\mathrm{NaHCO}_{3}$ は生体内では膵液怙よび intestinal fluid 中 に含まれており，大量に小腸内に分泌されている。した がつて,コレラ菌にとつて培養時に $\mathrm{HCO}^{-}{ }_{3}$ が存在する ことは，腸管内と類似の環境下に扔かれることになり， これらの現象は, その感染機構解明の手賏りになりらる るのと考兄られる。

この線織状構造物の本態および感染との関わりなどに ついては，目下検討中であるが今回はその予報として， これまで明らかになつた所見についてのべる。

\section{1983年ケニア国分離コレラ菌の性状}

○一瀬休生, 江原雅彦, 渡辺繁徳 (長崎大 - 熱研), 霜 鳥翔一（九大・医短大）

タンザニアにおいて1979年テトラサイクリン耐性コレ ラ菌の出現が Mhalu らによつて報告されて以来，隣国 のケニアに打いても薬郕耐性コレラ菌の出現に関心が払 われてきた。われわれは1983年,ビクトリア湖周辺地域 の基幹病院, 診療所の入院患者を中心に分離されたコレ ラ菌 245 株を対象にその性状検査を行つた。245 株は小 川型 236 株, 稲葉型 9 株で, untypable の 1 株を除けば すべてエルトール型であり，1株の cured 型を含むセレ ベス原型であつた。薬剤感受性試験では 245 株のうち, 184 株がテトラサイクリン，ストレプトマイシン，アン ピシリンの 3 郕に対し耐性を示す多倣耐性菌であること が判明した。コレラ流行が拈さまつた後に行つた環境調 查では, ビクトリア湖周辺のニアンザ地方の河川，井戸 水などからのコレラ菌分離を試みたが，コレラ菌は分離 されなかつた。しかし，43検体中 $46.5 \%$ から NAG ビブ リオが検出された。また，従来よりビブリオ属鑑別に用 いられていた O129 (Vibrio static agent) に対する感 受性テストでは196株中164株（83.7\%）が耐性菌である ことが判明した。

\section{8. エルトール，NAG ピブリオ両溶血秦の同一性} ○山本耕一郎, 仲宗根昇, 田辺将夫, 岩永正明 (琉球 大・医・細菌)

エルトールコレラ菌溶血素，NAG ビブリオ溶血素両 者の精製標品を用いて比較研究することを目的とした。 NAG ビブリオ溶血素精製法 (Infect. Immun. 45: 192) 
はそのままエルトール溶血素の精製に応用することがで きた。

両者はディスク電気泳動で同一の泳動度を示し，また SDS 電気泳動でも同一の分子量 $(60 \mathrm{~K})$ を有しているこ とがわかつた。また両者は同程度の溶血比活性を有して いた。

アフィニティークロマト精製抗 NAG ビブリオ溶血素 抗体を用いて Western Blotting を行つた。エルトール コレラ菌上清にはすべて分子量が $60 \mathrm{~K} の$ 位置に泳動され る NAG ビブリオと共通の抗原が存在していた。

これらのことからエルトール溶血素と NAG ビブリオ 溶血素は基本的に同一の溶血素であることが示唆され た。

\section{9. コレラ菌の毒素産生に影響をおよぼす諸因子につ} いて

○岩永正明 ${ }^{1)}$, 田辺将夫 ${ }^{1)}$, 山本耕一郎 ${ }^{1)}$, 仲宗根昇 ${ }^{1)}$, 江原雅彦 ${ }^{2}$, 内藤達郎 ${ }^{2)}$ (琉球大·医・細菌 ${ }^{1}$ ，長崎大 熱研・細菌 ${ }^{2)}$ )

In vitro でコレラ菌の毒素産生能を検査するために現 在用いられている方法は, 培地の成分およびその培養条 件が生体内のものとは余りにるかけはなれている。しか もその方法では菌数が $10^{10} / \mathrm{m} l$ という高密度に増殖する にもかかわらず毒素産生量はきわめて少なく, RPLA 法 によつて毒素を検出し得ない (1〜2 $\mathrm{ng} / \mathrm{m} l$ 以下) 菌株 も多くみられる。そこでわれわれは培養の条件を生体内 のものに近つけるよう試みて, コレラ菌に能率よく毒素 を産生させる培地・培養法を発案した。この新しい方法 によると, 菌数は $10^{8} / \mathrm{m} l$ の密度であるが毒素量は高濃 度となり，個々の菌についてみると従来の方法によるも のと比べて $1,000 〜 2,000$ 倍の毒素を産生していると考え られた。また従来の方法では毒素を検出し得ない多くの 菌株から毒素を検出することができた。

\section{0. コレラ业素の LPS との結合による無毒化と免疫}

\section{原性について}

○徳永英治, 今川義孝, 村岡東洋治, 大友信也, 近藤 誠一*，久恒和仁* (化血研, *城西大・薬)

コレラ毒素 (CT) と LPS ( $V$. cholerae NIH 41) の 複合体 (CT-LPS) の作製を行い，その毒性および免疫 原性について検討を行つた。

カルボキシル化 LPS とCT をカルボジイミド法によ り架橋させ, LPS へのカルボキシル基の導入量の違い により 4 種類の複合体 (CT-LPS I, II, III, IV) を作製
した。いずれの複合体す，毒性は CT の $10^{-2} \sim 10^{-3}$ に 低下したが，CT の抗原性は保持されていた。また， LPS の抗原性はカルボキシル基の導入量を少なくした LPS により作製した複合体ほどよく保持され，導入量 の增加にしたがつて低下した (CT-LPS IV >III > II > I）。いずれの複合体もマウスの腹腔内に投与すること により血中に高い抗毒素抗体を産生させた。一方抗 LPS 抗体の産生は CT-LPS IV を用いた場合にもつとも高 く, 以下 CT-LPS III, II, I の順であつた。CT-LPS を経口投与した場合，いずれの複合体でも血中に抗毒素 抗体が産生されたが，CT 投与の場合に比べて低かつ た。一方抗 LPS 抗体の産生は CT-LPS IV 投与の場合 のみに観察された。以上, CT-LPS 複合体は CT の毒 性が減弱され，また免疫原性も有していることが確認さ れた。

31. マウス・サイトメガロウイルスに対するモノクロ 一ナル抗体

○岡田政信, 栄鶴義人, 南嶋洋一 (宮崎医大・微生物) ハイブリドーマ法により，マウス・サイトメガロウイ ルス感染細胞に対するモノクローナル抗体産生細胞12株 を樹立し,それらが産生するモノクローナル抗体 (MCA) の性状を検討して，以下の結果を得た。

1.12種の MCA は ELISA により160倍から164,000 倍の抗体価を示した。

2. これらの MCA が認識する抗原を抗補体䖝光抗 体法 (ACIF) により検索した結果，8種の MCA のう ち, 感染細胞の核内抗原と反応するもの 3 種, 細胞質内 抗原と反応するもの 3 種，いずれの抗原とも反応しない もの 2 種であつた。

3. これらの MCA は微量中和試験により, 補体の 有無にかかわらず，いずれも中和活性を認めなかつた。

\section{2. ヒト血清中 ATL 関連抗体の解析}

○森内良三, 片峰 茂, 日野茂男, 宮本 勉, 木下研 一郎 (長崎大·医・細菌)

成人 $\mathrm{T}$ 細胞白血病患者血清中には，三好らの樹立した MT -1, MT - 2 細胞と特異的に反応する, いわゆる ATLA 抗体が存在することが知られている。この血清中の 抗体は ATLV/HTLV (Adulu T cell leukemia virus/ Human $T$ cell leukemia/lymphoma virus) 感染の分 布の解析や感染実験に有用性を示した。今回われわれは MT-2 lysate とウイルス粒子を抗原とした RIA 固相 法, および 3 H-leucine でラベルした MT-2 を抗原と 
した免疫沈降法を用い，間接營光法で陽性と判定された 4 群 (子供, 成人キャリアー, pre-ATL 患者, および ATL 患者) に打应抗体価，打よび各種ウイルスたん ぱくに対する抗体について比較検討したので報告する。

\section{3. 腫湯細胞溶解力をもつウシエンテロウイルスの型} 別

○松浦秀二, 新宮正久 (久留米大・医・ウイルス) oncolysis は腫瘍崩壊,しばしば腫瘍または塊りが縮小 したことに対して用いられる言葉であつて1963年 Hammon が用いたのが最初であろう。1971年 Nature に an oncolytic virus として Taylor らのウシエンテロウィ ルスの仕事をはじめて紹介したものがもつともこの言葉 を広めることになつたと考えられる。

われわれは10数年前より偶蹄類エンテロウイルスに関 する仕事をしてきたが，すでに 2,775 頭のウシより 316 株のエンテロウイルスを分離した。ウイルスを用いた抗 癌療法には抗原型の異なつたウイルスを多数用意する必 要がある。腫瘍細胞における増殖のよい 63 株について 血清学的型別を行つた。方法としてはプラック減少法に よつた。これらのウイルスは1型 (38株)， 2 型 ( 8 株)， 3 型 (10株)， 4 型 ( 2 株)， 5 型 ( 3 株)， 6 型 ( 1 株)， 7 型（1株）に分類することができた。これらの型の生物
学的性状についても述べてみたい。

34. 担㭧ヌードマウスにおける偶蹄類エンテロウイル スの効果

○新宮正久，浦川豊彦，今村宜寛（久留米大・医・ウ イルス)

われわれはウイルスを用いて癌を治療する目的で 4629 頭の偶踣類から 440 株のエンテロウイルスを HeLa 細胞 を用いて分離した。この中から選んだウシ，水牛，シカ， ブタ，イノシシ由来の 5 株のウイルスを用いてマウスお よびヒト由来の腫瘍細胞について組織培養おょび器官培 養を用いた in vitroの実験およびマウス移植癌 (Ehrlilch 癌および Sarcoma-180 癌) を用いた in vivo の実験を 行つてきた。これらの偶蹄類由来のウイルスは感染スペ クトルが多少異なるが一般に腺癌由来の細胞に有効であ つた。今回はヒト胃分化型腺癌由来 MKN-28 株および ヒト肺分化型腺癌由来 PC-9 株をヌードマウスの背部皮 下に接種し腫瘤を形成せしめたのちウイルスを直接腫瘤 内に注射しその効果をみた。すでに効果が確認されたウ シ，水牛，シカ由来のウイルスを用いたが，いずれのウ イルスも腫瘤の増殖の阻止, 縮小, 延命効果が観察でき た。また，腫瘤内でのウイルス増殖が確認され，何ら副 作用を認めなかつた。 